FOLIA SCANDINAVICA VOL. 24 POZNAŃ 2018 DOI: $10.2478 /$ fsp-2018-0006
S sciendo

PRESSto.

\title{
I GUDS NAMN. MIGRATION OCH FRÄMLINGSKAP I LENNART HAGERFORS LÄNGTA HEM. OM ETT MISSIONÄRSBARN I KONGO
}

\author{
HANNA RINDERLE \\ University of Freiburg
}

ABSTRACT. In this article I analyze the autobiographical novel Längta hem. Om ett missionärsbarn i Kongo (2003) by Lennart Hagerfors in order to understand how otherness is presented and how it is linked to the status of migration and being Swedish. I argue that the novel shows two distinct forms of otherness. The first is on the personal and individual level of the protagonist that is caused by his migration from Sweden to Congo. The other is on a cultural and national level, which situates Sweden in between the Congolese and French culture. While the first personal form of strangeness is viewed as problematic and must be overcome, the second form can be read as an expression of the positive Swedish self-image that situates Sweden outside of Europe's colonial history and therefore posits Sweden as a type of humanitarian Great Power or global conscience.

\section{INVANDRARLITTERATUR ELLER MIGRATIONSLITTERATUR?}

När Jonas Hassen Khemiri publicerade sin debutroman Ett öga rött 2003 dröjde det inte länge förän flera röster, både inom litteraturkritiken och -vetenskapen, hyllade boken om den unge Halim som den efterlängtade roman som gav alla invandrare en (skenbart) autentisk röst på den svenska litteraturmarknaden. Snart fanns det flera författare, exempelvis Alejandro Leiva Wenger eller Johannes Anyuru, som ansågs skriva en ny slags litteratur, den så kallade invandrarlitteraturen.

Inom litteraturvetenskapen kan invandrarlitteratur ses som ett sammanfattande begrepp för litteratur som är skriven av författare med invandrarbak- 
grund och som "hör till nya invandrargrupper i Sverige" (Gröndahl, 2002:35) eller sådana som vuxit upp i ett invandrartätt område och som skapar egna berättelser om Sverige (Jankowska, 2010:34). Deras verk präglas av en mångkulturell identitetskonstruktion och de tematiserar förhållanden mellan 'svenskar' och 'invandrare' utifrån ett invandrarperspektiv. Språkligt sett medför detta perspektiv ett så kallat multikulturellt språk (Trotzig, 2005:111), ett påstående som ofta diskuterats just i samband med Khemiris förstlingsverk (t.ex. Sjögren, 2003).

Men det finns och har också funnits personer som kritiserar en sådan kategorisering som skiljer mellan 'invandrarförfattare' och 'svenska' författare respektive 'invandrarlitteratur' och 'svensk', det vill säga 'vanlig' litteratur. En av de första och största kritikerna var författaren Astrid Trotzig som tillskrev analysen av den så kallade invandrarlitteraturen ett etniskt filter: Att begreppet bara används för att beskriva litteratur av författare som Jonas Hassen Khemiri, Johannes Anyuru eller henne själv visar att det är särskiljande, homogeniserande och rasifierande (Trotzig, 2005). I grunden definieras ett verk alltså av författarens 'ras' och ursprung. Det blir särskilt tydligt när man ännu en gång betraktar Ett öga rött: Khemiri är själv ingen invandrare utan född i Stockholm och bokens hyllade, autentiska rinkebysvenska är egentligen en lingvistisk konstruktion (Fegan, 2004; Behschnitt, Mohnike, 2007:91f).

Ett annat problem med begreppet invandrarlitteratur är att det bara fokuserar på det litterära främlingskapet ${ }^{1}$ som kommer utifrån till det egna 'hemmet', i det här fallet till Sverige. Det ignorerar dock att det också finns ett yttre främlingskap dit det egna kan förflytta sig eller migrera. Berättelser där en svensk person flyttar utomlands och beskriver sina erfarenheter passar inte in i kategorin invandrarlitteratur och måste i detta fall (alltså om man skiljer mellan invandrar- och annan litteratur) beskrivas som exillitteratur eller något liknande. Då behöver man två begrepp som egentligen beskriver ett och samma fenomen: migrationen och dess följder. I motsats till invandrarlitteratur samlas under begreppet migrationslitteratur olika slags berättelser "welche sich mit Themen des Kulturwechsels, der interkulturellen Begegnung und des interkulturellen Konflikts sowie der Fremdheitserfahrung und des Kulturschocks auseinandersetzen." (Herrmann, 2004:15) Detta begrepp tillåter ett

${ }^{1}$ Det främmande kan definieras som det okända, det som inte är det egna. Det egna och det främmande står i ett sammanhang vilket innebär att de behöver varandra. Därför är det främmande "vielmehr ein Relations- und Unterscheidungsbegriff zum Eigenen und somit ohne das Eigene gar nicht denkbar." (Gutjahr, 2002: 47) På det litterära fältet finns det olika möjligheter att beskriva det främmande: Det kan framställas som ett okänt ute som kommer in i det egna (Gutjahr, 2002: 51-54) liksom i den så kallade invandrarlitteraturen. Eller det egna kan resa till det okända, då blir det egna ett främmande subjekt i det okända ute (Gutjahr, 2002: 5459). Kända exempel är rese- och upptäckslitteratur samt migrations-, exil- eller koloniallitteratur. 
mycket bredare och öppnare fokus när det gäller litterära undersökningar. ${ }^{2}$ På det sättet undviker man också en, enligt Trotzig, rasifierande blick eftersom migrationslitteratur snarare fokuserar på konstverkets innehåll och poetik än på författarens efternamn (Frank, 2012:8). Då kan man även undersöka böcker som handlar om svenskar och den svenska kulturen som blir främmande, alltså berättelser där folk migrerar från Sverige till andra länder.

En författare som har skrivit flera böcker som passar in i denna kategori och har en Afrika-koppling är Lennart Hagerfors. Han debuterade med dagboksromanen Valarna i Tanganyikasjön (1985) om Henry Morton Stanleys upptäcktsresor. Hagerfors själv växte upp som missionärsbarn i olika städer i 1950-talets Kongo och delvis i Sverige. Sina upplevelser i båda länderna tematiserar han i den självbiografiska romanen Längta hem. Om ett missinärsbarn $i$ Kongo som publicerades 2003. ${ }^{3}$ Enligt boken kommer Hagerfors föräldrar första gången till Kongo redan under 30-talet. För modern är det "en romantisk dröm om undervisningens och evangeliets ljus i en mörk värld" (Hagerfors, 2003:6), för fadern däremot "en längtan efter förkunnelse och äventyr i vildmarken" (Hagerfors, 2003:6). Sina första barndomsår tillbringar Hagerfors med sina föräldrar och sina syskon på en missionsstation i Ngouedi, men en efter en skickas barnen till olika internatskolor, både i Sverige och i Kongo. Slutligen hamnar han på en internatskola i Pointe-Noire, åtskild från föräldrarna men med en vardag som innehåller en daglig fika och massor av fotbollsmatcher mot kongoleser. Han inser tidigt att hans liv helt påverkas av religionen: hans familj skickas till ett främmande land, jämfört med en svensk inkomst har de knappt pengar, familjen skiljs åt och allt detta sker i Guds namn.

Hagerfors berättare beskriver på olika ställen i boken att han inte känner sig hemma varken i Sverige eller i Kongo. Istället präglas han av en övergripande känsla av främlingskap. I den följande uppsatsen kommer jag att analysera hur det främmande iscensätts i Hagerfors bok, i vilken en svensk familj flyttar till det kulturellt okända, nämligen Kongo. Dessutom kommer jag att framställa på vilka olika nivåer det främmande och främlingskap presenteras i boken, om det bara existerar på ett personligt plan eller även på en övergripande, mer generell nivå. Slutligen ställer jag frågan hur tillståndet av främlingskap sammankopplas med att vara svensk. Jag utgår ifrån att det finns en ganska typisk identitetskonstruktion vad gäller berättaren: Han som

${ }^{2}$ Också Lars Wendelius väljer en bredare ansats i sin undersökning om Immigrant- och minoritetslitteratur på svenska 1970-2000 då han uppfattar författarnas "härkomst och tematik" (Wendelius, 2002:12) som centrala punkter inom den 'nya svenska litteraturen'. På så sätt öppnar han sina studier tematiskt, men författarnas härkomst och etnicitet spelar fortfarande en stor roll. Ett annat begrepp som är ännu bredare vore till exempel interkulturell litteratur.

32009 publicerade han dessutom en efterföljare till den första boken, Komma bort, som handlar om åren då han kommit tillbaka till Sverige för gott. 
migrant känner sig främmande både i det nya och det gamla hemlandet och han intar ett identitetsmässigt mellanförskap mellan en svensk och en kongolesisk identitet. Men detta mellanförskap existerar dessutom på en högre nivå då det också gäller den svenska kulturen som hamnar mitt emellan det koloniserade Kongo och den europeiska kolonialmakten Frankrike. Enligt min mening kan detta tolkas som ett litterärt uttryck för hur Sverige ser sin egen position i en postkolonial värld. Denna självbild löper från en "anti-imperialistisk och solidarisk nation" (McEachrane, Faye, 2001:9) fram till en humanitär stormakt (Körber, Löbel, 2009:17) eller till och med en sorts 'världssamvete' (Herrmann, 2004:23; Volquardsen, 2017:427).

\section{SVERIGE OCH KONGO ${ }^{4}$ - EN HISTORISK ÖVERBLICK}

Sveriges och Kongos gemensamma historia är starkt förknippad med landets kolonialisering. Kongo sågs länge som den 'sista okända' och därför också den 'mörkaste' platsen på jorden. Denna bild förändrades delvis när Henry Morton Stanley nådde Kongoflodens mynning 1877. Hans kartläggning gav både kolonisatörer och missionärer möjligheten att nå kontinentens inre, dess 'hjärta' (Berg, 1997:213). ${ }^{5}$ Nästan samtidigt med Stanley reste också den franske sjöofficeren och upptäcktsresanden Pierre Savorgnan de Brazza längs floden. År 1880 grundade han handelsstationen Brazzaville som sedan blev huvudstad i Franska Kongo. Denna koloni övergick 1910 till Franska Ekvatorialafrika (tillsammans med de andra franska kolonierna Gabon, Oubangui-Chari och Tchad) som i sin tur upplöstes 1958.

År 1884 deltog Sverige, som många andra europeiska länder, i en internationell konferens i Berlin under Otto von Bismarcks ledning vilken blev känd som Kongokonferensen. Målet var att dela upp Afrika under de europeiska kolonialmakterna och att reglera kontrollen över Kongobäckenet. Den största delen av regionen tilldelades den belgiske kungen Leopold II som privategendom men Franska Kongo blev bestående.

Även om Sverige knappt var en kolonialmakt $\mathrm{t}^{6}$ deltog flera svenskar både $\mathrm{i}$ olika kolonialiseringsprocesser (Lundahl, 2006) och var särskilt aktiva som missionärer sedan de första troende skickades ut till Etiopien under 1860-talet (Öhmann, 2010:131). År 1878 bildades Svenska Missionsförbundet som

${ }^{4}$ Denna överblick sammanfattar Sveriges gemensamma historia med både Belgiska och Frankska Kongo respektive Demokratiska Republiken Kongo och Republiken Kongo.

${ }^{5}$ Det mest kända exemplet för detta vanliga bildspråk är med säkerhet Joseph Conrads klassiker Heart of Darkness (1899/1995) som både tog upp brukliga imaginationer av Kongo men som också skapade respektive förstärkte och upprepade dessa.

${ }^{6}$ Bortsett från koloniseringen av Sapmi kan Sverige knappast kallas för en klassisk kolonialmakt, men ändå hade staten (förutom andra besittningar i Amerika och SaintBarthélemy) från 1650-1663 en koloni vid den så kallade guldkusten i dagens Ghana. 
snabbt bestämde sig för att satsa på Kongo med sina aktiviteter (Berg, 1997:213). År 1881, alltså bara några år senare, skickades den första svenska missionären, C. J. Engvall, ut i samband med Livingstones mission. Han fick dock snart återvända på grund av sitt hälsotillstånd men han ersattes av Nils Westlind och Karl Johan Pettersson. Missionens mål var i första hand evangelisationen men man fokuserade också på "vad vi idag skulle kalla för rent biståndsarbete" (Berg, 1997:215). Så byggde missionärerna till exempel skolor, var verksamma som läkare och sjuksköterskor och lärde sig kikongo. Det ledde till att det skapades ett första skriftspråk och Nils Westlind och Karl Edvard Laman översatte Bibeln till kikongo och skrev en ordbok samt en grammatik (Berg, 1997:215).

Svenska Missionsförbundet var mest verksamt i Belgiska Kongo men Svenska Baptistmissionen anslöt sig till verksamheten och satsade snarare på Franska Kongo respektive Franska Ekvatorialafrika. Edvard Vilhelm Sjöblom var den första missionären som skickades till Kongo av Baptistmissionen 1892 (Berg, 1997:224). I sin självbiografi I palmernas skugga uttalar han sig kritiskt mot Leopold II:s terror i Kongo, men han är en av ett fătal: "Helst av allt ville man slippa tala om övergreppen, våldet, och sin egen strukturella roll som kolonisatör." (Granqvist, 2008:102) Denna roll var så stark och omfattande att "[u]nder en period vid 1800-talets slut var svenskarna till antalet den tredje europeiska nationen i området efter belgier och engelsmän." (Berg, 1997:218) De hade olika uppgifter som sträckte sig från administrativa arbeten i fristaten, missionsarbete, soldater, ingenjörer eller sjömän till tjänster "på de fartyg som trafikerade landets floder" (Berg, 1997:218). Fyra år innan Kongo blev självständigt från Belgien, 1956, hade Svenska Missionsförbundet nitton stationer som alla låg $\mathrm{i}$ Kongodeltat (Granqvist, 2008:104).

Redan 1953 valdes Dag Hammarskjöld till FN:s generalsekreterare vilket hade en stor inverkan på den svenska självbilden (Körber, Löbel, 2009:18). Han engarerade sig inte bara inom olika dekoloniseringsprocesser och fredsbevarande insatser (Engh, 2009:68) utan tog framför allt ställning när det gällde Kongo och Patrice Lumumbas position som landets förste premiärminister. På liknande sätt agerade Olof Palme under sina år som Sveriges statsminister mellan 1969-1976 och från 1982 fram till sin död 1986. Han uppfattade sin roll som politiker så att han klart och tydligt sa sin mening angående dekoloniseringsprocesserna och kritiserade Sydafrikas apartheidsregim (Engh, 2009:71). 


\section{BERÄTTARENS DUBBLA FRÄMLINGSKAP}

Under Hammerskjölds tid som FN:s generalsekreterare föds Hagerfors berättare $^{7}$ i Eskilstuna (Hagerfors, 2003:57). Även om han tillbringar sina första månader i Sverige, är det först i Kongo som han förstår att han är "en människa" (Hagerfors, 2003:13). Sverige, hans faktiska hemland efter födelsen, markeras på så sätt inte som det första hemmet, utan det blir Kongo. Genom att Lennart blir människa just i Afrika tar Hagerfors upp den naturvetenskapliga diskursen om Afrika som människans ursprung. Tesen om Afrika som en "Cradle of Humankind" härstammar redan från 1871 när Charles Darwin (1982:202-204) var den första som antog att människosläktet härstammade från Afrika. Inom Hagerfors berättelse blir Kongo och Afrika på ett litterärt sätt åter igen till någon slags urtids- och ursprungsscen.

Ändå blir Kongo inte ett riktigt hem eftersom berättaren på olika sätt framställs som främmande. Den största och mest uppenbara distinktionen är hudfärgen som skiljer Lennart (och de andra svenskarna) från hans kongolesiska vänner. Genom att lägga fokus på den "ensamma vita pojken som hade fina kläder" (Hagerfors, 2003:99) eller att han är "vit [och] ägde fotbollen" (Hagerfors, 2003:165) uppstår två binära oppositioner, svart och vit. Dessutom förknippas att vara vit med att äga dyrbara saker, att stå högre på en social stege än de svarta kongoleserna. Därför är det just berättaren som är "annorlunda" (Hagerfors, 2003:165) i Kongo och inte de svarta kongolerserna, även om han försöker att passa in:

Ibland sökte jag mig en bit bort från trappan och lekte med ett gäng kongolesiska småpojkar. Vi åt levande flygmyror och vände ut och in på våra ögonlock [...]. Jag gjorde likadant. [...] Ibland vände hela gänget ögonlocken ut och in och alla fick en lysande blodröd strimma ovanför pupillen. Det var speciellt effektfullt mot deras mörka hy. De lärde mig hur man gjorde det. (Hagerfors, 2003:17f)

Den här beskrivningen av en barnslig lek tillsammans med kongolesiska pojkar liknar ett försök att 'going native'. I detta ursprungligen etnologiska uttryck förstår man en kulturell gränsöverskridning, i vanliga fall av européer som vill bli del av en främmande, ofta 'exotisk' kultur (Hamann, Kießling, 2017:149). Imitationen av de svarta killarna är en sådan gränsöverskridning men även om de lär honom hur man gör, hindrar hans vita hudfärg att det har samma effekt hos honom. Berättarens utseende gör det omöjligt att helt 'going native' och på så sätt bli en jämbördig del av gruppen. Det visar sig dock också att en gränsöverskridning är omöjlig på båda sidor. En vän till Lennart som enligt berättarens mamma inte är tillräckligt ren, tvättas av henne: "Efteråt

${ }^{7}$ Enligt den autobiografiska pakten (Lejeune, 1994:16-19) heter bokens berättare liksom författeren Lennart och de biografiska uppgifterna verkar liknande. 
tog hon på honom ett par shorts och en färgglad skjorta som jag vuxit ur. Förvandlingen var chockerande [...] Det var omöjligt att fortsätta leken. Det kändes som om jag förlorat honom för alltid.” (Hagerfors, 2003:19) I detta fall fungerar en försökt anpassning av den kongolesiska pojken till den svenska familjen inte heller, i stället har processen att göra den svarta pojken mer lik den vita berättaren motsatt effekt till följd. Han blir så främmande att Lennart inte längre kan interagera med honom.

Den svenska skolan i Kongo blir inte heller en plats som förmedlar en entydig kulturell tillhörighet utan snarare kunskaper som man varken kan använda i Kongo eller Sverige:

I Bibeln tvättade man ständigt varandras fötter och drack vin - det gjorde aldrig vi. I Sverige åkte man släde till Julottan och drack riktig mjölk - det gjorde aldrig vi. [...] Det fosterland vi läste om i skolan hade ingen likhet med det land vi mindes och kallade 'hemma i Sverige'. Det Sverige vi studerade var en del av skolan i Pointe-Noire, var lärobokskunskap, inte verklighet. Det var självklart att vi skulle lära oss alla Sveriges städer. (Hagerfors, 2003:109)

Det undervisas om ett prototypiskt Sverige som inte har några likheter med det verkliga Sverige eller med elevernas verklighet i Kongo. Istället blir fosterlandet Sverige ett tomrum som fylls med onödig information och som på så sätt blir till 'lärobokskunskap'. Påfallande är att Sverige och att vara svensk åter igen förknippas med vithet, i detta fall med släde, snö och mjölk. Men den här gången tillhör denna vithet det Sverige som eleverna i Kongo inte har tillgång till. Det som egentligen kännetecknar dem i deras nya hem, alltså den vita hudfärgen, tas nu ifrån dem eftersom de inte har tillgång till detta andra slags vithet.

Som resultat är Sverige inte likt det land de lär sig om i skolan. Det är till och med än mer främmande än Kongo när Lennarts familj återvänder dit. Först och främst presenteras det gamla hemlandet genom ett sinnligt främlingskap. Det gäller redan föräldrarnas första hemkomst innan barnen föddes. Även om allt är "välbekant" så finns det ändå synliga skillnader som förändrar Sverige, i detta fall är det på grund av ny och modern juldekoration (Hagerfors, 2003:54). När Lennart själv återvänder första gången lägger han märke till den främmande doften (Hagerfors, 2003:59) som skiljer Sverige ifrån Kongo. Dessutom är Sverige för honom "en skrämmande plats. Oftast befann man sig i halvdunkel. I Kongo var det bländande ljust eller svart natt." (Hagerfors, 2003:61) Här sker en inversion av den stereotypa bilden av Kongo som en "locus of darkness" (Brink, 1992:2) eftersom i Hagerfors berättelse är det Sverige som beskrivs som mörkt och skrämmande medan Kongo är ljust. Så blir Sverige, som tidigare associerades med färgen vit, det främmande och okända som ligger i mörkret. 
Liksom i Kongo spelar skolan i Sverige en stor roll för att skapa en känsla av främlingskap. Även om hudfärgen inte längre skiljer Lennart från de andra barnen, befinner han sig i ett "transittillstånd" som tvingar honom att lära sig "leva i en främmande värld." (Hagerfors, 2003:216) $\AA$ ena sidan är det hans kunnighet om Kongo och hans förflutna som utesluter honom från de övriga skoleleverna: "Jag var inte välkommen. Vilken skola kom jag ifrån? Svenska skolan i Pointe-Noire. Va? Den ligger i Kongo. Jaha. Jag kunde lika gärna ha pratat kikongo." (Hagerfors, 2003:217) Å andra sidan är det också hans okunnighet om Sverige som förstärker känslan av främlingskap. Det han lärt sig i den svenska skolan i Pointe-Noire visar sig vara oanvändbart eftersom man i det riktiga Sverige behöver veta "hur man klädde sig, vilka fotbollslag som fanns och vilka uttryck man använde." (Hagerfors, 2003:135) Som resultat blir inte heller Sverige ett riktigt hem; precis som i Kongo får han vara en del av olika gäng eller skolklasser, men Lennart förblir också i Europa främmande. Han uppvisar en identitetskonstruktion som varken är svensk eller kongolesisk utan den befinner sig i ett mellanrum.

En utväg ur den identitetsmässiga rotlösheten visar sig dock i Drott, det område där familjen bor. Där finns flera familjer med föräldrar som varit missionärer i Kongo: "Drott var en blandning av Sverige och Kongo, mest Sverige förstås. Men här gällde fromhetens lagar som i Kongo" (Hagerfors, 2003:221). Barnen som bor där har samma känsla av utanförskap både i Sverige och i Kongo. Genom att träffa andra ungdomar med samma problem blir Drott en 'third space' enligt Homi K. Bhabha (1994). I detta rum kan de komma överens om en egen identitet som slutligen blir normalitet: "Inga vanliga levnadsmönster hade någonsin gällt för mig. Normalitet var något för andra, för kongoleser, fransmän, missionsförbundare, lidingösnobbar, söderkisar. Men om jag, som drottkillarna, lärde mig leva med utanförskapet, se det som mitt naturliga tillstånd, min normalitet, kunde inget hota mig." (Hagerfors, 2003:222) Den negativt konnoterade rotlösheten förvandlas i detta tredje rum till ett positivt mellanförskap som tillåter en hybrid identitet och en oproblematisk blandning av olika roller i livet och Lennart sammanfattar:

Jag hade levt på Ngouedi, i Eskilstuna, Pointe-Noire, Brazzaville, Zanaga, Lindingö och nu Stockholm. Jag hade levt utan mamma och pappa men också tillsammans med dem. I Kongo var alla fromma utom hedningarna, i Sverige var alla ogudaktiga, utom missionsförbundarna. Det var naturligt att jag samma dag kunde vara en fjant $\mathrm{i}$ plugget, en snobb på Drott och en prydlig gudstjänstbesökare tillsammans med mamma och pappa. (Hagerfors, 2003:240) 


\section{DEN SVENSKA NATIONENS FRÄMLINGSKAP}

En binär och hybrid identitetskonstruktion, som den beskrivs i boken, är inget ovanligt inom migrationslitteraturen. Men i Längta hem finns det också en annan sorts främlingskap, som jag nu kommer att visa på. Detta främlingskap beträffar den svenska nationen, som placeras mitt emellan den kongolesiska och den franska nationen.

Som jag visat i den historiska överblicken, spelade språk en stor roll för svenska missionärer och framför allt kikongo blev centralt för deras arbete. Det visas också i Hagerfors bok eftersom språk, och först och främst kikongo, fungerar som en närmande faktor mellan svenskarna och kongoleserna. I likhet med berättarens identitet genomgår också kikongo en hybridiseringsprocess. Den tjänar till att föra den kongolesiska och den svenska kulturen närmare varandra, men samtidigt kommuniceras det i någon sorts mellanrum: "Mamma Vilma, en muminmamma i tropikerna [...] talade kikongo med gotländsk brytning" (Hagerfors, 2003:16). Genom att förbinda den gamla med den nya kulturen och inte helt ta över en av dem, skapas ett produktivt mellanförskap. Den person som mest symboliserar detta kulturella mellanförskap är Lennarts pappa. Framför allt när det gäller språk blir det tydligt att han med glädje identifierar sig med kongoleserna och att han står för ett svensk-kongolesiskt samarbete. Att det faktiskt handlar om ett samarbete visar sig när han "läste julevangeliet på kikongo, den kongolesiske pastorn Maloyi predikade på kiteke." (Hagerfors, 2003:193)

Ändå blir en viss grad av främlingskap bestående mellan de två kulturerna. Det beror mest på den religiösa missionen. Även om det finns en stark sympati och anpassning till varandra, är svenskarna dock "övertygade om sin oöverträffbarhet och frälsare." (Granqvist, 2001:112) Därför beskrivs kongoleserna som "hedningar" (Hagerfors, 2003:10) som ska omvändas i sin tro så att de kan "lämna det syndiga livet och följa Gud och hans son Jesus och bli en bättre människa, bli en kristen.” (Hagerfors, 2003:184) Det är svårt att inte se en hegemonial och kolonial maktkonstellation mellan svenskarna och kongoleserna i detta sammanhang eftersom den kristna tron tydligt framställs som mer värdefull. Det får en överordning av den svenska kulturen till följd ${ }^{8}$ vilken också visar sig utanför den religiösa sfären: "Pappa ville inte att en kongoles skulle slakta eftersom de aldrig bedövade djuren innan de skar upp halsen." (Hagerfors, 2003:37) Inte bara kongolesernas religion anses vara mindre värd utan kongoleserna verkar också vara mindre civiliserade än svenskarna. Det är en vanlig kulturell sammansättning inom en kolonial

${ }^{8}$ Att det vanligtvis inte uppfattas på så sätt beror nog mest på att kolonialism ofta ses $\mathrm{i}$ samband med en territorial besittning som svenskarna knappt hade (Naum, Nordin, 2013:4). 
samhällsordning då de europeiska kolonisatörernas kultur framställs som högre stående än de koloniserades (Osterhammel, 2009:20).

Samtidigt finns det ingen identifiering alls med den franska kolonialmakten. I motsats till en gemensam europeisk identitet markeras istället den franska kulturen som främmande och de svenska aktörerna avgränsar sig ifrån den. Dessutom demaskeras fransmännen som auktoritära (Hagerfors, 2003:163) kolonialherrar som prackar på en rasistisk och rasbiologisk världsbild. Idén om en barmhärtig och 'god' europeisk kolonialism förnekas av svenskarna: "Bredvid stod alltid en fransman i vit kortärmad skjorta och skrek order och förbannade de 'apor' och 'smutsiga negrer' som aldrig visade tillräckligt med ansvar för godset." (Hagerfors, 2003:103) Istället intar svenskarna snarare själv rollen som de koloniserade när de svenska pojkarna iakttar hur fransmännen firar sin nation vid en fotbollsmatch, "hur kolonins härskare arrangerade högtidliga parader till hemlandets ära." (Hagerfors, 2003:140). Genom ett försök att imitera kolonialmakten utan att riktigt nå dess nationalistiska ackuratess (de hissar både den svenska och den franska flaggan) påminner de om de koloniserades försök att härma kolonialmakten som Frantz Fanon beskriver det (2008:xiii).

Med denna distansering från den franska kolonialmakten intar svenskarna en anti-kolonialistisk position. Trots att de egentligen tillhör den europeiskvita minoriteten, sympatiserar de betydligt mer med de koloniserade kongoleserna. Att de ändå inte står på en bestämd sida utan mitt emellan de olika kulturerna förtydligar framför allt pappan. Detta sker åter igen på en språklig nivå, eftersom han "kunde konversera med franska kolonial-tjänstemän, berätta historier och skratta tillsammans med kongoleser eller gå fram till vägarbetare i Sverige och otvunget samtala om deras arbete." (Hagerfors, 2003:29) Det spelar ingen roll för honom vilken kultur han möter, han kan alltid interagera med dess tillhöriga.

I hela texten finns det endast några få passager där den unge berättaren ifrågasätter den svenska missionen. Det som får honom att tvivla är en av pappans handlingar:

Då tog pappa ett kliv mot den unge mannen och gav honom en örfil. [...] Pappa hade slagit en svart. Om det ändå hade varit en vit. Men han slog en svart. Det var första, och enda, gången jag såg honom göra det. [...]. Skuldkänslan kom över mig som en ångest. Det var inte jag som slagit, jag skulle aldrig ha gjort det. [...] Jag skulle aldrig glömma det. (Hagerfors, 2003:199)

Genom att använda våld mot en kongoles identifieras pappan snarare med de franska kolonialherrarna än med den vanliga svenska självbilden som innehåller att man sympatiserar med kongoleserna. Det är anmärkningsvärt att inte våldet i sig själv utan våldet mot en svart upprör Lennart. Den största skillnaden utgör i det här fallet alltså åter igen hudfärgen. Därför inträffar det, 
att just denna självbild om de 'goda svenskarna" ${ }^{9}$ också sviktar för Lennart. Dock distanserar han sig direkt från denna handling.

Eftersom Lennart betonar att det var enda gången fadern (eller en svensk överhuvudtaget) utövade våld mot en svart kongoles, spelar kritiken mot den svenska missionen och Sveriges roll i kolonialiseringsprocessen i övrigt knappt någon roll $\mathrm{i}$ berättelsen. Istället betonas att Sverige intar en plats mitt emellan Kongo och övriga europeiska makthavare: "Som en liten minoritet bland den övriga vita minoriteten fanns vi, svenska skolbarn och våra föreståndare och lärare. [...] Vi utmärkte oss genom vårt gulvita hår och våra exotiska sånger" (Hagerfors, 2003:103).

Å ena sidan finns det alltså en 'naturlig' likhet med fransmännen eftersom man kommer från samma kontinent och framför allt har samma ljusa hudfärg som skiljer de båda nationerna från de svarta. Ändå distanserar berättaren svenskarna från fransmännen eftersom han fördömer deras brutalitet och koloniala världsbild. $\AA$ andra sidan närmar sig svenskarna och kongolserna varandra genom en språklig förståelse. Ändå finns ett främlingskap eftersom svenskarna intar en högre ställning tack vare sin status som missionärer. På grund av religionen ser de kongolserna som 'hedningar' som ska omvändas. Resultatet blir att svenskarna alltid är främmande, både i förhållande till kongoleserna och fransmännen. Liksom Lennart gör det på en personlig nivå, intar svenskarna och svenskheten här en position mitt emellan de andra kulturerna.

\section{SLUTSATS}

Jag har påvisat flera olika nivåer av främlingskap i Hagerfors Längta hem. Den främsta faktorn som skapar främlingskap är skillnaden i hudfärg. Varken de vita svenskarna eller de svarta kongoleserna kan överskrida den gräns som dras på grund av optiska kännetecken och bli en del av den andra gruppen. På detta sätt uppstår en binär opposition mellan de två hudfärgerna. ${ }^{10}$ Denna opposition förstärks dessutom på grund av den kristna missionen. Eftersom svenskarna ser sig själva som bättre människor tack vare sin tro, jämfört med 'hedningarna', befinner de sig på en (skenbart) högre social nivå och manifesterar en samhällsordning som liknar ett kolonialt samhälle. Ett annat sätt att framställa främlingskap är genom kunskap respektive okunskap både när det gäller Sverige och Kongo. Detta visas framför allt i skolan, både i Sverige och Kongo. Sverige blir dessutom främmande för sinnena när missionärerna

\footnotetext{
${ }^{9}$ Denna bild finns dessutom också i Conrads berättelse (1995:78).

${ }^{10}$ Intressant nog finns det knappt någon hybriditet när det gäller hudfärgen, i Hagerfors Kongo är man svart eller vit.
} 
återvänder dit. Det finns alltså ett främlingskap både på en optisk/sinnlig och en handlingsorienterad nivå.

Därutöver finns det också ett kulturellt främlingskap som skiljer den svenska kulturen från den kongolesiska, här spelar hudfärgen åter igen en stor roll men även kulturella uttryck skiljer de båda kulturerna åt. Men det finns även en avgränsning gentemot den franska kulturen som egentligen tillhör samma vita minoritet. Genom att betona de orättfärdiga handlingar som fransmännen utför distanserar Hagerfors dessa två minoriteter ifrån varandra. Samtidigt ges svenskarna genom detta en högre etisk och moralisk status.

Sammanfattningsvis kan man säga att främlingskapet i Längta hem såväl har utslagning och en känsla av icke-tillhörighet som mellanförskap till följd. Detta sker inte bara på individplan utan också när det gäller de olika kulturerna. Skillnaden är att denna utslagning är problematisk för berättaren, han längtar och letar efter något slags tillhörighet. Slutligen behövs en 'third space' för att kunna utveckla en egen identitet. På det kulturella planet ser det helt annorlunda ut. Här är den mellanposition, som svenskarna befinner sig i, positivt konnoterad eftersom detta mellanförskap tillåter svenskarna att distansera sig från de koloniala fransmännen.

Det litterära mellanförskap som Hagerfors skapar i sin bok kan läsas som ett litterärt uttryck för självbilden om Sverige som en "anti-imperialistisk och solidarisk" nation (McEachrane, Faye, 2001:9) eller till och med en humanitär stormakt (Körber, Löbel, 2009: 17) när det gäller landets förhållande till Afrika. Denna självbild uppstod i första hand under efterkrigstiden. En faktor som främjade den här utvecklingen var olika stödprogram under 1950-talet som delvis utgick direkt från missioneringen. Ett exempel som May-Britt Öhman (2010) undersöker är programmet "Sverige hjälper" från 1955 och 1966. Sunniva Engh (2009) däremot ser ett sammanhang mellan den svenska självbilden och den neutrala position som Sverige intog under kalla kriget. Enligt henne hade Sverige ett starkt behov av fred eftersom man stod mellan de två fientliga blocken. Detta behov synliggjordes inte bara genom olika stödprogram utan också genom politiken under den tiden. Politiker som Hammarskjöld och Palme engagerade sig i en fredlig dekolonisering i Afrika för att stabilisera kontinenten och därmed också världspolitiken (Engh, 2009:70). Därefter överfördes åsikten till hela Sveriges medverkande i Afrikas koloniala historia: "Att vara 'svensk' är att kunna stå utanför kolonialismens historia och både vara kritisk mot de före detta kolonisatörerna och mer solidarisk med de före detta koloniserade" (McEachrane, Faye, 2001: 9). Att svenskarna "were in fact engaged in both colonial expansion, trade, exploration, and missionary activities" (Ipsen, Fur, 2009:7) spelar knappt någon roll 
i dagens självbild. ${ }^{11}$ Genom att placera Sverige, den svenska kulturen och att vara svensk mitt emellan den kongolesiska och den franska kulturen skapar Hagerfors ett litterärt uttryck för denna självbild som präglas av en känsla av moralisk och etisk överlägsenhet.

\section{REFERENCES}

Behschnitt, W., Mohnike, T. (2007): Interkulturelle Authentizität? Überlegungen zur 'anderen' Ästhetik der schwedischen 'invandrarlitteratur'. In: W. Behschnitt, E. Herrmann (ed.), Über Grenzen. Grenzgänge der Skandinavistik (s. 79-100). Würzburg: Ergon Verlag.

Berg, L. (1997): När Sverige upptäckte Afrika. Stockholm: Rabén Prisma.

Bhabha, H. (1994): The Location of Culture. London: Routledge.

Brink, A. (1992): Woman and language in darkest Africa: The quest for articulation in two postcolonial novels. Literator 13, 1-14.

Conrad, J. (1995): Heart of Darkness. Peterborough: Broadview Press.

Darwin, C. (1982): Die Abstammung des Menschen (transl. H. Schmidt). Stuttgart: Kröner.

Engh, S. (2009): The Conscience of the World? Swedish and Norwegian Provision of Development Aid. Itinerario 33/2, 65-82.

Fanon, F. (2008): Black skin, white masks (transl. R.Philcox). New York: Grove Press.

Fegan, A. (2004): Dom tar våra ord. arena 5, 40-43.

Frank, S. (2012): Hvad er migrationslitteratur? Kritik 203, 2-10.

Granqvist, R. (2001): "Virvlande svarta lemmar" och "goda svenskar" i Kongo i hundra år. Om svensk rasism i vardande. In: M. McEachrane, L. Faye (ed.), Sverige och de Andra. Postkoloniala Perspektiv (s. 107-131). Stockholm: Natur och Kultur.

Granqvist, R. (2008): Med Gud och kung Leopold i ryggen. En berättelse om svensk mission i Kongo. Ord\&Bild 2, 98-117.

Gröndahl, S. (2002): Invandrar- och minoritetslitteratur i Sverige. Från förutsättningar till framtidsutsikter. In: S. Gröndahl (ed.), Litteraturens Gränsland. Invandrar- och minoritetslitteratur i nordiskt perspektiv (s. 35-70). Uppsala: Centrum för multietnisk forskning.

Gutjahr, O. (2002): Fremde als literarische Inszenierung. In: O. Gutjahr (ed.), Fremde (s. 47-67). Würzburg: Königshausen und Neumann.

Hagerfors, L. (1985): Valarna i Tanganyikasjön. Stockholm: Norstedts.

Hagerfors, L. (2003): Längta hem. Om ett missionärsbarn i Kongo. Stockholm: Norstedts.

Hagerfors, L. (2009): Komma bort. Stockholm: Norstedts.

Hamann, C., Kißling, M. (2017): Going Native. In: D. Göttsche, A. Dunker, G. Dürbeck (ed.), Handbuch Postkolonialismus und Literatur (s. 149-153). Stuttgart: J. B. Metzler Verlag.

Herrmann, E. (2004): Postkolonialer Diskurs und Literatur der Migration im Nordischen Kontext: Prolegma zu einer anderen Art von "Reiseliteratur". TijdSchrift voor Skandinavistiek, 15-40.

Ipsen, P, Fur, G. (2009): Introduction. Itinerario 33, 7-16.

Jankowska, P. (2010): Sverigeskildringar i samtida svenska romaner. Debatten om fenomenen och begreppen "invandrarlitteratur" och "invandrarförfattare". Acta Sueco-Polonica 16, 33-49.

Khemiri, J. H. (2003): Ett öga rött. Stockholm: MånPocket.

11 Även om Ebbe Volquardsen (2017:427) hävdar att postkolonial kritik făr en större akseptans i Sverige än till exempel i Danmark - så finns det en permanent utställning om den svenska missionen i Kongo i Stockholms Etnografiska museet - är det fortfarande ett tema som inte diskuteras särskilt mycket i den svenska offentligheten. 
Körber, L., Löbel, K. (2009): "Afrika” und "der Norden”. Konzeptualisierungen und Verschränkungen zweier Regionen. Acta Germanica 37, 17-32.

Lejeune, P. (1994): Der autobiographische Pakt (transl. W. Bayer). Frankfurt a. M.: Suhrkamp. Lundahl, M.: Nordic Complicity? Some Aspects on Nordic Identity as "Non-Colonial" and Non-Participatory in the European Colonial Event. Revisiting Nordic Colonialism. Retrieved from www.rethinking-nordic-colonialism.org/files/index.htm (2017-11-05).

McEachrane, M., Faye, L. (2001): Inledning. In: M. McEachrane, L. Faye (ed.), Sverige och de Andra. Postkoloniala Perspektiv (s. 7-16). Stockholm: Natur och Kultur.

Naum, M., Nordin, J. (2013): Introduction. Situating Swedish Colonialism. In: M. Naum, J. Nordin (ed.), Scandinavian Colonialism and the Rise of Modernity. Small Time Agents in a Global Arena (s. 3-16). New York: Springer.

Öhman, M. (2010): 'Sweden Helps': Efforts to Formulate the White Man's Burden for the Wealthy and Modern Swede. Kult 7, 122-142.

Osterhammel, J. (2009): Kolonialismus. Geschichte, Formen, Folgen. München: C. H. Beck.

Sjögren, A. (2003): Först ut att skriva på invandrarsvenska. Västerbottens Kuriren 2003-08-04.

Trotzig, A. (2005): Makten över prefixen. In: M. Moa (ed.), Orientalism på svenska (s. 104-127). Stockholm: Ordfront.

Volquardsen, E. (2017): Skandinavien. In: D. Göttsche, A. Dunker, G. Dürbeck (ed.), Handbuch Postkolonialismus und Literatur (s. 425-427). Stuttgart: J. B. Metzler Verlag.

Wendelius, L. (2002): Immigrant- och minoritetsliteratur på svenska 1970-2000. Uppsala: Centrum för mulitetnisk forskning.

\section{Hanna Rinderle}

Albert-Ludwigs-Universität Freiburg im Breisgau

Skandinavisches Seminar

Platz der Universität 3

79098 Freiburg

Germany

hanna.rinderle@skandinavistik.uni-freiburg.de 